\begin{tabular}{|l|l|l|}
\hline \multicolumn{2}{|c|}{ PublisherInfo } \\
\hline \hline PublisherName & $:$ & BioMed Central \\
\hline \hline PublisherLocation & $:$ & London \\
\hline \hline PublisherImprintName & $:$ & BioMed Central \\
\hline \hline
\end{tabular}

\title{
A pediatric critical care site with a difference
}

\begin{tabular}{|l|l|l||}
\hline \multicolumn{2}{|c|}{ ArticleInfo } \\
\hline \hline ArticleID & $:$ & 4281 \\
\hline \hline ArticleDOI & $:$ & $10.1186 /$ ccf-2000-webreport1383 \\
\hline \hline ArticleCitationID & $:$ & webreport1383 \\
\hline \hline ArticleSequenceNumber & $:$ & 22 \\
\hline \hline ArticleCategory & $:$ & Web report \\
\hline ArticleFirstPage & $:$ & 1 \\
\hline \hline ArticleLastPage & $:$ & 3 \\
\hline \hline & & RegistrationDate : 2000-3-14 \\
\hline ArticleHistory & $:$ & OnlineDate \\
\hline \hline ArticleCopyright & $:$ & Current Science Ltd2000-3-14 \\
\hline \hline ArticleGrants & $:$ & \\
\hline \hline ArticleContext & $:$ & 1305444 \\
\hline \hline
\end{tabular}




\section{Overview}

This small site is run by Jay D Fisher, a pediatric emergency physician from University Medical Center in Las Vegas (affiliated with the University of Nevada School of Medicine). The site is basically a collection of academic resources for pediatric physicians and students, but resembles a journal in that some features are updated monthly. The site is accredited by Physicians Online.

\section{Overview}

Every month the editor (Dr Fisher) identifies four or so papers of relevance to pediatric critical care physicians; these are usually recent publications in one of the major peer-reviewed journals. In addition to summarising the main study findings, he includes an interesting (and well-written) perspective on the validity and clinical relevance of the findings. The site also features a collection of classic articles in pediatric emergency medicine, each of which is accompanied by Dr Fisher's commentary on the significance and historical context of the paper.

Another regular feature is the 'case of the week', which is occasionally supplemented with a 'rash of the week' and even 'noise of the week'! After describing the history and presenting complaint (often using clinical images), the user is asked to make a diagnosis or decide on the next step of treatment from multiple answers. A full explanation of the correct answer is given. The 'picture of the week' section is organised in a similar way, and all cases are archived and searchable.

Under the heading 'Study Guides/Data Synthesis' are clinical management guidelines on problematic areas of pediatric emergency medicine, such as poisoning, skull fracture, shock and occult bacteremia. These are comprehensive documents that provide an evidence-based approach to the diagnosis and management of these conditions.

Finally the site has a collection of links in pediatric emergency medicine and general pediatric medicine, and an external link to the University Medical Center website.

\section{Other comments}


The site was up-to-date at time of review, and new content is posted at least monthly. The site has a very basic structure so navigation via the browser buttons is possible. Nonetheless, intrasite navigation buttons, and in particular a 'home' button, would certainly facilitate this. Pages are not individually named so bookmarks will always take you to the home page.

\section{Evaluation}

This quirky site takes a refreshingly humorous approach to a highly specialised area of medicine. While the content is medically and editorially sound, it is made more accessible by the lighthearted tone and Dr Fisher's commentaries. The content would be useful for both medical students and practising physicians looking to brush up on their diagnostic skills and keep up-to-date with the literature. However I think the site would benefit greatly from a mission statement on the home page, explaining precisely what the site is, who it is for and what it has to offer.

\section{References}

1. The Completely Different Pediatric Emergency Medicine Journal. [http://www.pediatricemergency.com/] 